\title{
A Lost Opportunity : The Flawed Implementation of Assertive Multilateralism (1991-1993)
}

James D. Boys

\section{OpenEdition}

\section{Journals}

Electronic version

URL: https://journals.openedition.org/ejas/9924

DOI: 10.4000 /ejas. 9924

ISSN: 1991-9336

Publisher

European Association for American Studies

\section{Electronic reference}

James D. Boys, "A Lost Opportunity : The Flawed Implementation of Assertive Multilateralism (1991-1993)", European journal of American studies [Online], 7-1 | 2012, document 6, Online since 17 December 2012, connection on 08 July 2021. URL: http://journals.openedition.org/ejas/9924 ; DOI: https://doi.org/10.4000/ejas.9924

This text was automatically generated on 8 July 2021.

Creative Commons License 


\title{
A Lost Opportunity : The Flawed Implementation of Assertive Multilateralism (1991-1993)
}

\author{
James D. Boys
}

1 Bill Clinton did not seek the presidency to initiate an activist foreign policy in the aftermath of the Cold War, but instead to champion domestic affairs and economic renewal. However, his foreign policy advisers entered office with their own, often differing, interpretations of the United States' position in the post-Cold War era. After the unity demonstrated by the Gulf War, the U.S. Ambassador to the United Nations advocated a tactic of Assertive Multilateralism with which to provide international leadership. This acknowledged President George H.W. Bush's approach to foreign policy and was viewed as a way to reduce costs, casualties and American exposure in overseas deployments. Despite these hopes, Assertive Multilateralism did not prevail - why was this the case? Twenty years on, this paper analyses the concept of Assertive Multilateralism, and specifically, the challenges posed to its continued implementation by the Somali mission. The paper finds that unrealistic mission expectations, the prioritizing of domestic agendas, and an inability to control the mission narrative all contributed to cause a fundamental shift in the United States' implementation of foreign policy and raised doubts over its continued commitment to the United Nations. Ultimately, the events in Somalia ensured that foreign policy become a tool with which to attack an administration focused on domestic affairs and unwilling to expend political capital on overseas operations.

Given the historic junction at which the Clinton Administration came to power it is surprising that more has not been written on its foreign policy initiatives. Nancy Soderberg noted in 2005 "no insider of the Clinton White House has discussed the broad challenges involving the use of force and diplomacy faced by the administration." Such a pattern continues, with no former Clinton official having adequately addressed the administration's development of foreign policy. Accordingly, the administration risks being viewed as merely the age 'between the Bushes', between a Cold War and a War on 
Terror. However, President Clinton's time in office coincided with historic global events and his handling of them was crucial to the development of world politics at the dawn of the twenty-first century. A consideration of policy documents and interviews with former members of the Clinton national security team reveal an administration seeking to define America's role in the rapidly changing world. ${ }^{1}$ As Richard Sale notes, "the popular image of Bill Clinton as a foreign policy leader is one of a man who was tardy, vacillating, irresolute, always timidly reluctant to use force and heading an administration lacking in singleness of focus or ruthlessness of drive." ${ }^{2}$ Only by attempting to understand the efforts of the Clinton Administration to address the challenges of the post-Cold War era and devise policy with which to address it, can we hope to comprehend the reasoning behind the actions of his successors, both of whom inherited Clinton-era policies and practices, including the rejection of Assertive Multilateralism.

3 Although the term 'Assertive Multilateralism' is credited to Madeline Albright it was a philosophy of international leadership that the Clinton Administration inherited from the previous Bush White House. Under George H. W. Bush, the United States had led United Nations' multilateral operations to oust Saddam Hussein from Kuwait and to relieve hunger in Somalia. These missions had lent credence to Bush's concept of a New World Order. Such an approach to foreign policy owed much to the character of the president as well as to timing. George H. W. Bush was by nature a team player who had developed relations with heads of state and foreign dignitaries since his days as U.S. Ambassador to the U.N. and as Director of Central Intelligence. He was, therefore, well positioned to lead a multilateral coalition and maximize the historical timing associated with the collapse of the U.S.S.R. For most of its existence, the United Nations had been stymied by the Cold War stalemate, but with the collapse of the Soviet system, an opportunity beckoned for the U.N. to fulfill its original mandate. The United Nations appeared to offer a new vehicle for international operations in the 1990s that enabled the United States to lead from the front, whilst reducing its defense expenditure as part of a much anticipated peace dividend. During the 1991 Gulf War and initially in Somalia, this was a bi-partisan model for foreign policy, advocated by a Republican President and endorsed by a Democratic Congress. It was an approach to policy that Bush's successor intended to continue, with every expectation of continued bi-partisan support.

4 When Bill Clinton succeeded President Bush, he named Madeleine Albright as U.S. Ambassador to the United Nations. A member of Jimmy Carter's National Security Council, Albright had spent the 1980 s as a faculty member at Georgetown University, developing the concepts that she would later christen 'Assertive Multilateralism. ${ }^{3} \mathrm{Her}$ concept was that if the United States no longer had the political will nor the resources to act as a global policeman, it was in America's interests to form coalitions to do so. It meant, "that when America acted with others, [America] should lead in establishing goals and ensuring success." ${ }^{4}$ Vitally, however, this did not preclude unilateral action in self-defense or in defense of vital interests. Albright was adamant that Assertive Multilateralism was a tactic not a goal and was, therefore, an acceptance of President Bush's actions in the 1991 Gulf War. Accordingly, it was an approach that should have received strong bi-partisan support. However, the Somali mission was the last gasp of the internationalist Republican generation as personified by President Bush, whose approach to policy implementation had garnered Republican support in Congress, but which came under attack once it was adopted by the Clinton Administration. Richard 
Nixon referred to Assertive Multilateralism as "naïve gobbledygook." ${ }^{5}$ Clinton's critics attacked the tactic as ideologically driven and interpreted the phrase to imply that the administration intended to subcontract U.S. foreign policy to the United Nations. The Clinton Administration, they claimed, believed "American unilateralism was the principal sin to be avoided, as if to atone for a shameful past." ${ }^{6}$ Albright, however, insisted to a House subcommittee as late as June 1993 that Assertive Multilateralism was in America's best interests. ${ }^{7}$ Soon, however, the administration was forced to explain where U.S. interests lay in Somalia.

5 The plight of the Somali people became apparent to the world during 1992, whilst America's attention was on the presidential campaign. ${ }^{8}$ On the few occasions that foreign policy was addressed, Somalia was not considered a priority when contrasted with crises evolving in Bosnia, the former Soviet Union, China, Haiti, the Middle East and Iraq. Despite the lack of attention on the campaign, on April 24, the United States approved U.N. Resolution 751, establishing the United Nations Operation in Somalia (U.N.O.S.O.M.) and provided almost half of the emergency relief materials. ${ }^{9}$ These efforts, however, were severely hampered as relief flights were looted, food convoys hijacked and workers assaulted, causing questions to be asked in Congress about the potential for direct military action. ${ }^{10}$ The unwillingness of the United States to dispatch troops to aid the humanitarian effort undermined President Bush's concept of a 'New World Order,' but the administration's inaction owed much to domestic politics and electoral timing. Throughout the 1992 campaign George H.W. Bush was forced to act in response to allegations that he was a 'foreign policy president' with little regard for the economic woes of the country. Once his plans for a second term had been thwarted, he returned to the multilateral approach to foreign policy that had been at the heart of his presidency. On December 9, 1992, the first American troops landed in Somalia under the auspices of Security Council Resolution 794, as U.N.O.S.O.M. gave way to United Task Force (U.N.I.T.A.F.), codenamed Operation Restore Hope. Between December 1992 and March 1993, U.N.I.T.A.F. saved countless lives in Somalia and delivered supplies to those in need. The short-term aspects of the plan succeeded, enabling the U.S. commitment to end, as U.N. Resolution 814 concluded the U.N.I.T.A.F. mission and gave rise to U.N.O.S.O.M.II. ${ }^{11}$ This reduced the American force from 25,000 to just 1,100 rapid reaction troops and 3,000 logistical support personnel. The American withdrawal, however, emboldened Somali warlords, including General Mohammed Aidiid, who targeted the multinational peacekeeping force, resulting in the deaths of 24 Pakistani peacekeepers. On October 3, 1993, Task Force Ranger, an American Special Forces unit dispatched specifically to apprehend Aidiid, became embroiled in a mission that should have taken no longer than an hour but dragged on throughout the night, as two Black Hawk helicopters were lost. The ensuing battle cost 18 American lives in the worst single day for battlefield casualties of the entire Clinton Presidency. It caused the abandonment of Assertive Multilateralism as a model of policy implementation, the eventual departure of the U.N. Secretary General and led to a reappraisal of the use of the United Nations by the United States in future overseas ventures.

Why did this happen? Similar events in Vietnam and subsequently in Iran and Afghanistan failed to cause such a reversal in policy. ${ }^{12}$ Why then, did these casualty rates, which were in line with overall expectations, cause such a fundamental shift in direction? The explanation is contained in a series of flaws inherent in the Somali mission, the failure of two administrations to prioritize Somalia at the expense of domestic affairs and the Clinton Administration's inability to control the narrative of 
the mission in a rapidly changing geo-political landscape. These elements contributed to ensure not only the failure of an otherwise successful operation in Somalia, but also the demise of an otherwise successful tactic of Assertive Multilateralism.

\subsection{Mission Flaws}

7 The model for Assertive Multilateralism was the 1991 Gulf War, initiated to repel Iraqi forces from Kuwait. This was a clearly defined mission with defined operational limits. Once these were achieved the mission ended. Despite the success in the Gulf, the Somali operation proved to be a very different mission, in which unrealistic expectations proved to be critical. The key elements that made an assertive multilateral tactic a success in the 1991 Gulf War were absent in the design of the Somali mission. The planning was too truncated; the decision to deploy was based on emotion not logic and the United States did not retain control of the mission as the operation's parameters were altered to incorporate the ambitions of the United Nation's Secretary General. These flaws in the design of the Somali mission contributed to undermine the continued feasibility of Assertive Multilateralism.

8 First, truncated planning was a contributing factor in the failure of the Somalia mission, which compromised the deployment and led to doubts over the viability of Assertive Multilateralism. On November 20, 1992 the National Security Council's Deputies Committee began a series of four meetings on Somali at which Under Secretary of Defense Paul Wolfowitz suggested deploying ground troops. Five days later, on November 25, President Bush decided that U.S. combat troops should lead an international force to Somalia. ${ }^{13}$ Famine and disease were claiming up to 1,000 Somali lives a day but the White House claimed it could establish order and be out by Bush's last day in office, January 20, $1993 .{ }^{14}$ The Pentagon demurred, believing that the operation could take at least six months. Defense Secretary Cheney advised the president, "we can't have it both ways. We can't get in there fully until mid-December. And the job won't be done by January 19."15 The president, however, initiated the deployment despite objections from his senior military advisers. The out-going team conceded that the Clinton Administration was being handed "a difficult situation" as the withdrawal of the American contingent before Inauguration Day was now considered "unrealistic."16 The operation was initiated only after the president had lost his bid for re-election, decided upon in four rapidly held meetings at the Deputies Committee of the National Security Council, implemented with little time for a consultation with Congress and the mission's timescale was in flux before the troops had been dispatched. ${ }^{17}$ The planning and preparation that had defined an assertive, multilateral approach in the build up to the 1991 Gulf War were clearly lacking in this instance.

9 Also absent was a rational reason for intervention as policy makers relied on emotion and ignored pragmatic advice. In 1991 an assertive multilateral approach had succeeded because nations recognized the potential threat created by a policy of appeasement in the Persian Gulf and the threat that this posed to oil supplies. No such explanation existed to justify the decision to deploy in Somalia. Instead, the decision was based on emotion in a classic example of what became known as 'the CNN effect'; an emotional response to images of starving Somalis compelled President Bush to support the U.N. mission and a similar reaction to images of murdered American troops led to 
the end of U.S. involvement the following year. ${ }^{18}$ Between these two events emotion continued to play a role in the Clinton Administration's approach to the mission as key advisers pursued a quintessential American liberal tradition at the expense of pragmatism.

As President Bush's final multilateral mission had crept into a subsequent administration without having devised an exit strategy, the incoming Clinton foreign policy team was forced to develop an ad hoc strategy to deal with the situation. Dick Moose, designated Under-Secretary of State for Management, was tasked with devising a Presidential Study Directive (P.S.D.) examining options in Somalia. He recommended withdrawal. However, when this blunt report received a muted response from Anthony Lake and Sandy Berger, ${ }^{19}$ "he suspected he was saying something that they did not want to hear." ${ }^{20}$ Lake and Berger were proponents of a humanitarian led foreign policy and feared that Moose's suggestion may return Somalia to its previous state of anarchy. Such action was anathema to the two men, who both valued the American liberal tradition of trying to export goodwill and a better life to the Third World. Lake in particular had a special interest in the plight of Africa and was committed to the operation's completion. Moose's advice, however, should have been heeded, as events in Somalia became the nadir of foreign intervention for the entire Clinton presidency.

11 In making policy based on emotion, the out-going Bush national security team ensured that the Somali operation was flawed from the beginning. Their actions meant that the Clinton Administration, so determined to focus on the domestic renewal of America, assumed office with 25,000 troops deployed in an ill conceived, rapidly executed mission. This was compounded by the emotional, ideological determination of key members of the Clinton Administration to reject pragmatic policy options and pursue a policy that bore no resemblance to anything that had been espoused on the campaign trail, and which had no place in their Grand Strategy policy that eventually emerged. The reliance on emotion ensured that lessons from the previous successful adoption of an assertive multilateral approach were ignored as the United States surrendered control of the mission in Somalia.

In 1991, the United States took the lead in the implementation of the U.N. mission to expel Saddam Hussein's forces from Kuwait. The U.S. had taken an assertive, multilateral approach and led a coalition to achieve its stated goals. Once these had been completed, the mission ended. In Somalia, the mission appeared to have succeeded by spring 1993. This led the United States to hand over operational command and to withdraw the majority of its forces as U.N.I.T.A.F. morphed into U.N.O.S.O.M.II on May 4, 1993. However, this was the latest in a series of hastily made decisions regarding the Somali operation. The Clinton Administration had endorsed Security Council Resolution 814, which authorized the U.N. to rebuild Somalia, as it enabled the withdrawal of most American troops. It had, however, meant that a small number of American forces remained in Somalia and that the U.S. was no longer in control of the mission parameters, which had changed considerably. Leaving personnel in Somalia ensured that the United States retained a lingering commitment to a mission that was of no importance to the administration. The mission remained multilateral at this point, but U.S. involvement was anything but assertive. Retaining a commitment, however small, guaranteed that what was initiated under Resolution 814 became associated with the Clinton Administration, despite the lead taken on the issue by the U.N. Secretary General, Dr Boutros Boutros-Ghali, whose personality and 
commitment to social engineering led to a shift in the mission parameters and to the final key flaw in the mission plan.

By the Secretary General's design, U.N.O.S.O.M.II utilized expanded enforcement power and included a mandate to disarm Somali factions. The new mission went beyond providing humanitarian relief and committed the U.N. to stabilizing Somalia, restoring law and order, creating an infrastructure and helping to establish representative government. Under Resolution 814, therefore, the United Nations attempted to build a new nation from the ruins of Somalia. It was this concept of Nation Building that proved to be contentious and so detrimental to the Clinton Administration. However, this was a United Nations' policy and was neither initiated nor imposed by the White House. ${ }^{21}$ Indeed, as the transition to U.N.O.S.O.M.II ensured that American forces were cut substantially, and because the operation was going to plan, few in Washington voiced concern. Even the House of Representatives, which presented many subsequent challenges to the foreign policy endeavors of the Clinton White House, decisively passed a resolution "endorsing the nation building mission and favoring the use of American troops to support it, for several years if necessary." ${ }^{22}$ Such endorsements were quickly forgotten following the American deaths in Somalia, as the recriminations poisoned relations between Washington and the U.N. in the years that followed. However, the Somali mission was never a priority of the Clinton White House and had been inherited from the previous Bush Administration. Nation Building was a goal of the U.N. and was endorsed by the Clinton Administration and Congress only once the majority of American troops had been withdrawn. ${ }^{23}$ This was clarified in a letter President Clinton sent to Congress in which he spelt out his position: "We went to Somalia on a humanitarian mission...The U.S. military mission is not now nor was it ever one of nation building." ${ }^{24}$ This was not a policy that could be used to justify any American fatalities, and meant the events in Somalia ended any hopes of relying on the U.N. to handle future ethnic conflicts. It also ended the administration's ability to utilize a tactic of Assertive Multilateralism. ${ }^{25}$

The key components that had made an assertive multilateral tactic a success in the 1991 Gulf War were absent in the design of the Somali mission. The planning was truncated; the decision to deploy was based on emotion rather than pragmatism and the United States did not retain control of the entire mission as the mission parameters were altered to incorporate the ambitions of the United Nations' Secretary General. These flaws within the Somali mission contributed to the demise of Assertive Multilateralism as a viable policy option for the United States as their impact was irrevocably tied to domestic politics.

\subsection{The Impact of Domestic politics}

Flaws in the Somali mission plan were not sufficient to end the U.S. commitment to Assertive Multilateralism. These problems were exacerbated by the failure of the Bush and Clinton Administrations to prioritize the challenges in Somalia and instead, focus on domestic issues. For Bush, this entailed reducing his focus on foreign affairs as he sought re-election during a recession. Following his failed re-election bid Bush was determined to demonstrate benevolence during the interregnum that extended to the Somali people but not necessarily to the incoming administration. For the Clinton Administration, Somalia was seen as a problem to be dealt with by the Deputies Committee of the National Security Council and kept away from the president. 
Madeleine Albright could advocate Assertive Multilateralism, but the White House had domestic priorities. This created a self-perpetuating situation; inattention to the Somali mission due to a focus on domestic priorities contributed to American fatalities. This tragedy then ensured that political adversaries were able to exploit the Somali debacle for their own ends and derail the administration's domestic policy programs.

The first domestic challenge to the continuation of Assertive Multilateralism arose during the presidential election of 1992. President George H.W. Bush benefited greatly from his implementation of an assertive multilateral approach to the 1991 Gulf War, securing not only a military victory, but also an approval rating of $90 \%{ }^{26}$ This caused senior Democrats to avoid the upcoming election, increasing his hopes for a second term. By 1992, however, the American economy was in recession.Bush's decision to raise taxes ensured he faced a challenge not only from the Democratic Party, but also from the right of the Republican Party by Pat Buchanan, forcing Bush to adopt a far less internationalist approach to secure the nomination. The Clinton campaign focused on the economy, campaigning to Bush's left on domestic matters and to his right on foreign affairs. ${ }^{27}$ Assailed from left and right, the president appeared indecisive. The campaign sought to "blunt Bush's advantage on [foreign affairs] and in boxing terms, keep a left jab in his face," ensuring that President Bush was so worried about being seen as a foreign policy president, "he failed to take advantage of his strengths." 28

These factors ensured that calls for the United States to intervene in Somalia throughout 1992 went unheeded until after the election. It was the misfortune of the Somali people to be suffering at a time when President Bush could ill-afford to demonstrate compassion for foreign nationals. Only after his defeat did President Bush declare the Somali deployment, "necessary to address a major humanitarian calamity and avert related threats to international peace and security and protect the safety of Americans and others engaged in relief operations." ${ }^{29}$ Left unexplained was the timing of the deployment, which international agencies and members of Congress had requested throughout $1992 .{ }^{30}$ Having allowed the issue to drift and deteriorate throughout the election, the White House acted only once the president was beyond the will of the electorate, ensuring the deployment was "a major intervention, undertaken by a lame-duck president, without congressional authority and not in response to a local invitation." ${ }^{31}$ By failing to secure a viable exit strategy, President Bush inadvertently provided the conditions for political disaster and an end to bipartisan support for Assertive Multilateralism. This was exacerbated by a presidential transition that has, in retrospect, been viewed as one the most disorganized in U.S. history.

Having called for a more pro-active U.S. foreign policy throughout the campaign, there was little that President-Elect Clinton could say in opposition to Bush's plans..$^{32}$ Bush and Clinton discussed the Somali operation once during the transition, whilst Bush's National Security Adviser, Brent Scowcroft kept in touch with Sandy Berger, head of Clintons' foreign policy transition team. However, there was no mutual formulation of policy and no one was asking the Clinton team for ideas or approval. ${ }^{33}$ The failure of the incoming and outgoing administrations to agree on the scope of the mission and on exit strategies did much to undermine the continued utilization of Assertive Multilateralism once the mission faltered. Once this occurred, the lack of attention afforded by both administrations to the deployment became all the more apparent. The Bush Administration's decision to intervene in Somalia was agreed at the Deputies 
Committee of the National Security Council, a process that continued under the Clinton Administration as the Deputies Committee, rather than the full National Security Council, oversaw events in Somalia. ${ }^{34}$ There was no Principals Meetings on Somalia until tragedy had struck because "the operation seemed to be going well. The mission seemed to be on track for transfer to the U.N., with U.S. forces scheduled to be out by early to mid-1994." ${ }^{35}$ This ensured that Cabinet-level officials were "not sufficiently attentive" ${ }^{36}$ to the Somali operation and that President Clinton was removed from the policymaking process in the initial stages of the deployment. This reinforced a view of the president as being inattentive to foreign policy and involved only in domestic political affairs.

During the summer of 1993 the Clinton Administration was preparing its health care reform plans, as designed by a committee headed by the First Lady, Hillary Clinton. Her involvement ensured that this was both political and personal, and any crisis risked diverting attention from this flagship agenda. ${ }^{37}$ Accordingly, Clinton's domestic advisers were clear on what they wanted the foreign policy team to do with Somalia: "Hand over the job of keeping order to a United Nations peacekeeping force, soon." 38 This reflected the real focus of the administration, which did not lie in the Horn of Africa, but rather in implementing domestic legislation, especially the First Lady's health care reforms. The White House was adamant that nothing should impede this, and certainly not a foreign policy initiative inherited from the previous administration. This was placed at risk when, having withdrawn 20,000 troops from Somalia, President Clinton acquiesced to the recommendation of Chairman of the Joint Chiefs, Colin Powell, and the Deputies Committee to deploy Task Force Ranger to Somalia to prevent further losses to the U.N. detachment. ${ }^{39}$ Once more, a rapid decision, made at a subCabinet level drew American forces deeper into a land where U.S. interests were impossible to define and in an operation that had nothing to do with the administration's priorities. President Clinton's anger at the subsequent U.S. deaths in Somalia reflected his realization that the incident threatened to dominate the news to the detriment of his health care proposals and his entire presidency. ${ }^{40}$ President Clinton's fears were realized in a TIME/CNN poll that indicated only $43 \%$ support for a continued U.S. presence in Somalia, down from 79\% in January 1993. ${ }^{41}$ As the American death toll climbed, public support for the mission waned. The American public's regard for the Clinton Administration's overall foreign policy suffered from the events in Somalia, as approval ratings tumbled to $34 \%{ }^{42}$ Americans viewed the Somali mission as a repeat of the 1982 intervention in Beirut - another operation to keep a peace that did not exist.

The Bush and Clinton Administrations failed to prioritize the Somali mission and instead, focused on domestic issues relating to elections and presidential legacies. ${ }^{43}$ The lack of adequate policy coordination during the interregnum exacerbated this, meaning the Clinton team inherited a challenge to their efforts to enact health care reform. Until the morning of October 3, 1993 the Somali operation was on track as far as the Americans were concerned. One tragic event caused a shift in U.S. foreign policy that had been initiated by a president of one party and continued by the president of another. The Clinton Administration had advocated a pro-active policy of Assertive Multilateralism but the events in Somalia demonstrated "a cavernous gap between the administration's soaring rhetoric and its much more judicious actions." ${ }^{44}$ 


\subsection{Inability to Control the Mission Narrative}

21 Due to the timing of the mission, the Somali operation fell between two administrations and as such there was a lack of commitment to the cause in the Clinton White House. The inability of the White House to control the narrative in Somalia and to counter criticism of the mission, proved to be a serious impediment to the continued viability of Assertive Multilateralism. It had not been a campaign priority and threatened to divert attention from the domestic agenda. A fundamental problem for the clinton Administration was that the Bush White House presented the mission as a simple one of humanitarian necessity. However, Operation Restore Hope was a far more complex and perilous undertaking than was conveyed to the American public. ${ }^{45}$ Once Operation Restore Hope (U.N.I.T.A.F.) was ended and the majority of U.S. troops returned home, the American public, and indeed many in the White House forgot about Somalia. After the handover of control in May 1993, President Clinton welcomed home a number of American servicemen at a ceremony on the White House lawn, telling his troops, "You have proved that American leadership can help to mobilize international action to create a better world." ${ }_{46}$ Whilst the event was intended to honour the troops, the administration also sought to project Bill Clinton as a credible Commander-in-Chief. It was also part of the mission narrative: U.S. troops had deployed, delivered aid and returned within six months. However, once the Special Forces were ordered into Somalia in August with the ensuing fatalities, the narrative became more difficult to explain. Instead of successfully portraying the U.N. mission and the U.S. Ranger deployment as two distinct elements, the lines became blurred. The White House was unable to convey the narrative of these two distinct missions, one of relief and the other, reciprocity, ensuring that the true nature of American intentions was called into question, along with the competence of the administration.

The deaths caused the House Appropriations Committee moved to impede future humanitarian operations by demanding that presidents give fifteen days notice before dispatching troops and provide estimated costs, projected duration, the goals and defined U.S. interest. These moves, by a Democratically controlled Congress, reinforced growing concerns about President Clinton's ability to serve as Commander-in-Chief. President Clinton was in the difficult situation of having to address and rectify mistakes made by both his own team and by members of the Bush Administration. "The Somalia tragedy shocked Clinton into talking control of his foreign policy and his bureaucracy." ${ }^{47}$ Clinton ordered all U.S. troops out of Somalia by March 31, 1994 and dispatched a contingent of 1,700 troops to Somalia to facilitate the withdrawal. As Anthony Lake conceded, the decision made itself: "To do otherwise would have made it open season on Americans around the world. The potential message: Kill and humiliate our people and the United States will immediately retreat." 48 The President's decision prevented a revolt in Congress, where legislators welcomed the firm deadline for withdrawal, which many viewed as a declaration of independence from the U.N., its Secretary General and his policy of Nation Building. The notion of blaming the incident on the U.N. became doctrinal, as the administration and members of Congress implicated Boutros-Ghali. Yet despite assurances that U.S. troops would never again be placed under U.N. command, all involved knew that Task Force Ranger had been under direct U.S. command at all times. The top U.N. official in Somalia was an American, and it was he, Admiral Howe, who most sought the deployment of Task Force Ranger to 
Mogadishu. There was no escaping the fact that "Task Force Ranger was a wholly American production." 49

The administration's inability to control the mission narrative was exacerbated by a deliberate distortion of events and intentions, as the Somalia mission and the attending tactic of Assertive Multilateralism were utilized by Clinton's opponents in their effort to regain the White House. The Somali debacle contributed to the Republican victory in the 1994 mid-term elections and the new Senate Majority Leader, Bob Dole, focused on foreign policy in his bid to defeat Clinton in the 1996 Presidential election. He claimed that under Clinton, "U.S. foreign policy [had] been marked by inconsistency, incoherence, lack of purpose, and a reluctance to lead." To Dole, the choice was stark, "to allow international organizations to call the shots as in Somalia, or to make multilateral groupings work for American interests, as in Operation Desert Storm." 50 This effort to re-write history by removing mention of the Bush Administration and blurring the sequence of events in 1993 became a mantra for critics of Assertive Multilateralism, which included former presidents. George H.W. Bush noted, "After I left office the mission changed into trying to bring the Somali warlords to justice. It was classic mission creep...When the starvation was ended, we should have brought our troops home and let the U.N. peacekeeping force take over." ${ }_{51}$ What the Clinton Administration failed to convey was that this is precisely what happened. 20,000 U.S. troops had left Somalia on schedule, leaving 1,100 troops under a U.N. rapid reaction team and 3,000 support personnel. Only when the safety of the U.N. mission was called into question was Task Force Ranger dispatched. Like Bush, Richard Nixon described the mission in Somalia as being "a lesson in how not to conduct U.S. foreign policy," and insisted that America should discern a way of "using the U.N. not being used by it." ${ }^{52}$ Nixon's former secretary of state, Henry Kissinger noted, "the new Clinton Administration reduced the number of American troops from 28,000 to 4,000...as a result of the new mission, a battle took place, costing a score of American lives." ${ }_{53}$ However, neither Nixon nor Kissinger accurately addressed the situation. The U.S. commitment to U.N.O.S.O.M. II was minimal, most U.S troops had withdrawn once the U.N. took control of the mission and the events of October 3 had occurred in a bid to apprehend forces that had murdered U.N. troops. This was a distinction lost on many, including the former president and his secretary of state, as well as those in Congress who had initially voted in favor of the U.N.O.S.O.M. II mission. Former Clinton adviser Michael Mandelbaum noted, "Whoever won the election in 1992 would have had to face a tough choice in 1993 regarding Somalia...The Bush people might have made a different choice than Clinton, and just pulled out, but they can't now say that they could have avoided that choice." ${ }^{54}$ When President Clinton responded to the Bush criticism he clearly had to restrain himself. "It may have been naive for anyone to seriously assert in the beginning you could go into a situation as politically and militarily charged as that one, give people food, turn around and leave, and expect everything to be hunky-dory." ${ }_{55}$

\subsection{Key Implications}

The Somali mission had implications not only for politics and policy, but also for personnel and operations. It was recognized that "the scale of the foreign policy reversals in Somalia destroyed the administration's willingness to pursue foreign policy goals aggressively." ${ }^{56}$ It led to a change in philosophy at the White House and 
destroyed the administration's capacity to advocate an approach of Assertive Multilateralism in the future. Just as President Bush had delayed a deployment due to the 1992 election cycle, so too did the 1994 and 1996 elections impact the administration's thinking as it sought to extract itself from Somalia. The policy response to the Somali mission and the attendant concept of Assertive Multilateralism took the form of Presidential Decision Directive 25: 'Reforming Multilateral Peace Operations.' (PDD-25) Delivered to the president in May 1994, this was the first comprehensive policy on multilateral peace operations in the post-Cold War era. It developed new standards to determine future participation in peacekeeping operations and restated the importance of Congressional support for such missions. The report concluded that whilst peacekeeping should remain a component of U.S. foreign policy, it would be "a part of our national security strategy, not the centrepiece." ${ }^{57}$ Early drafts of this document had considered an expansion of U.N. operations with the U.S. being committed to support such engagements militarily, economically and politically as well as support for a standing U.N. army and the placing of U.S. forces under United Nations' command. Such policies became politically untenable following the events in Somalia, which caused a re-write that clarified the position of the administration with regard to command and control of American forces in U.N. operations: "The President will never relinquish command of U.S. forces. That is inviolable." ${ }^{58}$ The Somalia mission "interrupted an important policy debate upon the use of peacekeeping troops in operations. People had been very enthusiastic about the concept but it was seen as a bad idea after Somalia, and there was a pulling back from this idea from that point onwards." ${ }^{59}$ A State Department official said "We'll get back to it at some point and hopefully some sort of concept of collaborative action with the U.N. will emerge, but it is not going to be what it was." ${ }^{60}$ Despite this hopeful assertion, U.S. policy towards the United Nations failed to recover from the incident and resulted in a relationship of mutual suspicion that still endures. The divisions between the United Nations and the United States that became apparent during the administration of George W. Bush, over issues of rendition and the war in Iraq, had their origins, therefore, in the early years of the Clinton era. ${ }^{61}$

The fallout from Somalia impacted not only the philosophical embrace of Assertive Multilateralism but also the administration's capacity to engage overseas in any form of multilateral action. "The events in Somalia created on over-hang that was a consistent reminder in other events...It provided a realization that future losses or casualties would produce a response in Congress similar to that provided by the events in Mogadishu." ${ }^{2}$ The crisis and the Congressional reaction ensured that President Clinton was initially unable to recommend a deployment of U.S. troops to Bosnia under a U.N. peacekeeping role, for fear of crossing "the Mogadishu Line"63. Just as Somalis had suffered throughout 1992, the suffering in Bosnia continued due to the repercussions of perceived failings in U.S. foreign policy. Similarly, the fallout from Somalia coincided with the massacres in Rwanda, as the U.N. plan to send 5,500 troops to alleviate the situation was vetoed by Madeline Albright, operating under instructions from Washington. Despite protests from the White House that the plan had received limited support from other nations, the reality was that "it was politically impossible to go into central Africa" following the events in Somalia. ${ }^{64}$ Indeed, the publication of PDD-25 was a tacit admission that whilst the Clinton Administration may have wanted to solve the world's problems, neither the United States nor the international community had the resources or the mandate to do so. Nancy Soderberg 
noted, "After Somali there was just no enthusiasm for putting troops on the ground anywhere. I think it delayed aggressive engagement in Bosnia, it certainly delayed any response in Rwanda, but I don't think we ever really stepped away from multilateralism, it was more a question of assessing where multilateralism worked and where it didn't work." ${ }^{65}$ Involvement in future peacekeeping operations required that vital national or allied interests be at stake and that a clear commitment to win existed. "Peacekeeping is not at the center of our foreign or defense policies," ${ }_{66}$ Anthony Lake asserted in February 1994, reversing the administration's initial policy.

\subsection{Conclusion}

Assertive Multilateralism appeared to offer the domestically focused clinton administration a method by which to address economic renewal whilst still adopting what it viewed as a bi-partisan approach to maintaining a global presence. The Clinton Administration saw this as a way to spread expenditure, casualties and the focus of hostility away from the United States and on to the shoulders of a global organization that had the potential to live up to its mandate in the post-Cold War era. However, this was predicated on the false belief that the American people would tolerate casualties in distant lands when no national interest was at stake and that Congress would continue its Cold War era support of the president in matters of world affairs. Neither assumption proved to be viable as the administration's efforts to initiate a policy of Assertive Multilateralism met Congressional opposition in the face of public dismay over the deaths in Somalia. Somalia proved to be the start of a new decade of conflict as bitter infighting, civil wars and intra-national conflicts dominated the 1990s. Rather than reinforcing American efforts to export human rights and to engage in conflict resolution, the events in Somalia served to convince Americans that such internal disputes were of no concern to the world's sole superpower. The Somali mission lacked a clear objective beyond its initial intervention, something Anthony Lake recognized only in retrospect: "In 1993 we in the Clinton Administration inherited a situation without a strategy or a timetable. And sadly, as we struggled with key issues, we probably made an ill-defined mission worse." ${ }^{67}$

President Clinton may have sought to define a new foreign policy for a new geopolitical age, but his willingness to delegate foreign policy to his advisers, whilst he focused on the domestic policy, reinforced the perception that he was disengaged from the foreign policy decision-making process. The debacle in Somalia blighted Clinton's first year in office. The initial deployment had worked as planned. It was only after American Special Forces were dispatched, months after the initial deployment had been withdrawn, that the decisive casualties were inflicted within a matter of hours. Had this not occurred, Assertive Multilateralism may have been a far more viable option. It had not meant to encapsulate the administration's entire approach to foreign policy, but it had been the approach with which to engage with the United Nations in multilateral operations. ${ }^{68}$ Events in Somalia, however, confirmed President Clinton's worst fears about foreign policy being "a murky business, outside the reach of domestic presidential control, with greater possibility for negatives than positives, out of which relatively little good could come." ${ }^{69}$ President clinton found that the world continued to impede on his time as "the end of the Cold War heralded not an end to history but rather, a host of unexpected threats, some new and others ancient." ${ }^{\prime 0}$ The entire political establishment learnt an important lesson; there would be no further 
deployment of ground forces to locations where U.S. national interest did not exist or could not be adequately defined - peacekeeping operations were not considered a justifiable cause for American casualties. The deaths of 18 American servicemen on 3 October 1993 proved to be instrumental in ending a brief era of bi-partisan support for multilateral operations under United Nation's mandates and caused the Clinton Administration to fundamentally reconsider its commitment to the organization and to peacekeeping operations in general.

\section{NOTES}

1. Interviews have been conducted with Anthony Lake (National Security Adviser 1993-1997), Leon Fuerth (National Security Adviser to Vice President Gore 1993-2001), Nancy Soderberg (Member of the National Security Council 1993-1996) and Morton Halperin (Pentagon 1993, NSC 1994).

2. Richard Sale, Clinton's Secret Wars, (New York: St. Martin's Press, 2009), xi.

3. Michael Dobbs, Madeleine Albright: A Twentieth Century Odyssey (New York: Henry Holt and Company, 1999), 349.

4. Madeleine Albright, Madame Secretary, A Memoir (London: Macmillan Press, 2003), 176.

5. Richard Nixon, Beyond Peace (New York: Random House, 1994), 32

6. Peter W. Rodman, Director of National Security Programs, Nixon Center for Peace and Freedom, quoted in Steven Erlanger, "The U.S. and the U.N.; Now, Who Needs Whom More?" New York Times, 7 July 1996, D5.

7. Madeleine Albright, "Myths of Peace-keeping," Statement before the Subcommittee on International Security, International Organizations, and Human Rights of the House Committee on Foreign Affairs, 24 June 1993, cited in U.S. Department of State Dispatch 4, no. 26 (24 June 1993), 464.

8. By early 1992 Somalia had descended into anarchy with no recognisable, functioning government or legal infrastructure. Foreign nationals were evacuated as up to 30,000 Somali's perished from malnutrition and conflict. See U.S. House of Representatives, Committee on Foreign Affairs, Consideration of Miscellaneous Bills and Resolutions, Vol.2, 19 February 1992, 120.

9. For the official United Nations record on the mission, see United Nations Operation in Somalia Mission Background, available at the United Nations, http://www.un.org/Depts/DPKO/Missions/ unosomi.htm. See also The United States Army in Somalia, http://www.history.army.mil/ brochures/Somalia/Somalia.htm

10. See U.S. House of Representatives, Select committee on Hunger, Somalia: Case for Action, (22 July 1992); U.S. House of Representatives, Committee on Foreign Affairs, Subcommittee on Africa, A Review of U.S. Policy and Current Events in Kenya, Malawi, and Somalia (23 June, 1992).

11. For the official United Nations record on this mission see Completed Peacekeeping Operations: UNOSOM II, available at the United Nations, http://www.un.org/en/peacekeeping/missions/past/ unosom2.htm.

12. President Nixon was re-elected despite the deaths of 20,000 U.S. troops in Vietnam in his first term. 15 deaths convinced President Clinton to leave Somalia. See Stephen S. Rosenfeld, "Clinton Administration Proving Reluctant World Cop," The Washington Post, 17 October 1993. 
13. George Bush, "Humanitarian Mission to Somalia," Department of State Dispatch (4 December 1992)

14. See William J. Clinton, My Life (London: Hutchinson, 2004), 550 and Bruce W. Nelan, "Taking on the Thugs," Time Magazine, 140/24, 14 December 1992, 26.

15. Colin Powell, My American Journey (New York: Random House, 1995), 565.

16. Martin Fletcher, "U.S. Troops Ready to Land in Mogadishu," The Times, 2 December 1992, 12.

17. Congress did not approve the Somali mission until after Bush left office. The Senate voted to approve on 4 February 1993 and the House voted in favour on 25 May 1993.

18. See Lee H. Hamilton with Jordan Tama, A Creative Tension: The Foreign Policy Roles of the President and Congress (Washington, D.C.: Woodrow Wilson Centre Press, 2002), 27.

19. Anthony Lake served as National Security Adviser (1993-1997). Berger served as Deputy National Security Adviser (1993-1997) and National Security Adviser (1997-2001).

20. David Halberstam, War In A Time of Peace: Bush, Clinton and the Generals (New York; Scribner, 2001), 254.

21. The White House was happy to offer support for the nation building exercise but nothing more: "The process of nation building in Somalia will take some time...we owe it to ourselves and to Somalia - to help UNSCOM succeed." See Peter Tarnoff, "U.S. Policy in Somalia," Statement before the Senate Foreign Relations Committee, 29 July 1993, cited in U.S. Department of State Dispatch 4, no.32, 9 August 1993, 23-24.

22. George J. Church, 'Anatomy of a Disaster,' Time Magazine 142/16, 18 October 1993, 40.

23. Due to the prevalence of regional clans, the viability of developing a functioning state in Somalia was always going to be a challenge. See I.M. Lewis, Somali Culture, History and Social Institutions (London: London School of Economics and Political Science, 1981) and Richard H. Shultz, Jr., "State Disintegration and Ethnic Conflict: A Framework for Analysis," in Annals (September 1995), 75-88.

24. Public Papers of the Presidents, William J. Clinton, vol.1 (1993), Message to the Congress Transmitting a Report on Somalia, 13 October 1993, 1740.

25. Thomas Omestad, "Foreign Policy and Campaign ‘96," Foreign Policy 105 (Winter 1996/1997)

43.

26. Halberstam, War In A Time Of Peace,9.

27. See E.J. Dionne, “Clinton Turns Sights to Foreign Policy," Washington Post, 29 July 1992, A1.

28. Author's interview with Anthony Lake, 14 September 2004.

29. President George H.W. Bush, Letter to Congressional Leaders on the Situation in Somalia, 10 December1992.

30. In June 1992 a bi-partisan group of eighty-eight members of Congress urged the president to make relief efforts in Somalia his 'highest priority,' see U.S. House of Representatives: Select Committee on Hunger, Somalia: Case for Action (22 July, 1992), 85-87.

31. William G. Hyland, Clinton's World: Remaking American Foreign Policy (Westport, CT: Praeger Press, 1999), 53.

32. See John M. Goshko, "U.N. Orders U.S.-Led Military Force in Somalia," Washington Post, 4 December 1992, A1.

33. Bush's national security adviser Bent Scowcroft advised Nancy Soderberg "Don't worry. We'll have the troops out by January 20." Soderberg, The Superpower Myth, 36.

34. Author's interview with Leon Fuerth, 8 June 2004. By 3 October 1993 the NSC had held 38 Principal Committee Meetings (none of which had addressed Somalia) and 60 Deputies Committee meetings ( 9 of which had addressed Somalia).

35. Soderberg, The Superpower Myth, 38.

36. Warren Christopher, quoted in Michael R. Gordon with John H. Cushman Jr. "After Supporting Hunt for Aidid, U.S. Is Blaming U.N. for Losses," New York Times, 18 October 1993, A1. 
37. The Health Care Bill was sent to the Hill on 27 October 1993, with momentum having been lost when the president had to deal with the death of the soldiers in Somalia.

38. George J. Church, "His Seven Most Urgent Decisions," Time Magazine 141/4, 25 January 1993, 20.

39. Gordon with Cushman Jr. "After Supporting Hunt for Aidid, U.S. Is Blaming U.N. for Losses," A1.

40. The president reportedly exploded, "I can't believe we're being pushed around by these twobit pricks." See George Stephanopoulos, All Too Human, A Political Education (New York: Little and Brown, 1999), 214.

41. J.F.O. McAllister, "When to Go, When to Stay," Time Magazine 142/14, 4 October 1993, 40.

42. Gallup Poll, November, 1993, quoted in Diane Hollern Harvey, "The Public's View of Clinton," in The Post-Modern Presidency: Bill Clinton's Legacy in U.S. Politics, ed. Steven E. Schier (Pittsburgh, PA: University of Pittsburgh Press, 2000), 128.

43. An internal Clinton Administration report concluded "the policy had been largely left in the hands of midlevel officials as it shifted from a humanitarian mission...towards a military effort... While Lake had kept the president informed...the principles never sat down among themselves, or with the president, to review the shift." See Soderberg, The Superpower Myth, 36.

44. Jonathan Clarke, "Contempt for Foreign Policy is Showing," Los Angeles Times, 26 October 1993, B7.

45. Mohamed Sahnoun, Somalia: The Missed Opportunities (Washington, D.C.: United States Institute of Peace Press, 1994)

46. George J. Church, "Somalia, Mission Half Accomplished," Time Magazine 141/20, 17 May 1993, 42.

47. Soderberg, The Superpower Myth, 40

48. Anthony Lake, Six Nightmares: Real Threats in a Dangerous World and How America Can Meet Them (Boston: Little, Brown, 2000), 129.

49. See Walter Clarke and Jeffrey Herbst, "Somalia and the Future of Humanitarian Intervention," Foreign Affairs 75 (March-April 1996), 73 and Mark Bowden, Black Hawk Down (London: Bantam, Press, 1999), 487.

50. Bob Dole, "Shaping America's Global Future," Foreign Policy, Issue 98, (Spring 1995) 35.

51. George Bush, "All The Best, George Bush": My Life in Letters and Other Writings (New York: Scribner, 1999), 580.

52. Nixon, Beyond Peace, 36

53. Henry Kissinger, Does American Need A Foreign Policy? Towards A Diplomacy for the Twenty-First Century (New York: Simon Schuster, 2001), 266.

54. Thomas L. Friedman, “A Broken Truce: Clinton vs. Bush In Global Policy,” New York Times, 17 October 1993, A1.

55. Public Papers of the Presidents, William J. Clinton, vol. 2 (1993), 1753.

56. James Adams, “Clinton Foreign Policyin Tatters," Sunday Times, 17 October 1993, Overseas Section.

57. Lake, Six Nightmares, 153.

58. Press Briefing by National Security Adviser Anthony Lake and Director of Strategic Plans and Policy General Wesley Clarke, The White House, 5 May 1994.

59. Author's interview with Morton Halperin, 22 June 2004.

60. Gordon with Friedman, "Details of U.S. Raid in Somalia: Success So Near, a Loss So Deep," A1.

61. James D. Boys, "What's So Extraordinary About Rendition?" The International Journal of Human Rights, 15/4, May 2011, 591.

62. Author's Interview With Leon Fuerth, June 8, 2004

63. Clarke and Herbert, "Somalia and the Future of Humanitarian Intervention", 70. 
64. Mike Sheehan, military adviser to Madeleine Albright, quoted in Dobbs, Madeleine Albright: A Twentieth Century Odyssey, 356.

65. Author's Interview With Nancy Soderberg, 26 May 2004.

66. Anthony Lake, 'The Limits of Peacekeeping,' New York Times, 6 February 1994, Sec IV, 17.

67. Lake, Six Nightmares, 166.

68. Author's Interview With Nancy Soderberg, 26 May 2004.

69. Halberstam, War In A Time Of Peace, 264.

70. Sidney Blumenthal, The Clinton Wars: An Insider's Account of the White House Years (London: Penguin Books, 2003), 60.

INDEX

Keywords: Assertive Multilateralism, Gulf War, National Security Council, Somalia, Task Force Ranger, United Nations

\section{AUTHORS}

\section{JAMES D. BOYS}

Senior Visiting Research FellowKing's College London Associate ProfessorRichmond University London 